\title{
Binding of $\beta$-galactosidase from rat epididymal fluid to the sperm surface by high-affinity sites different from phosphomannosyl receptors
}

\author{
M. A. Sosa, M. A. Barbieri and F. Bertini* \\ Instituto de Histología y Embriología, Facultad de Ciencias Médicas, Universidad Nacional de \\ Cuyo-C.C. 56, Mendoza (5500), Argentina
}

\begin{abstract}
Summary. $\beta$-Galactosidase, known to be secreted by epithelial cells lining the rat epididymal duct, binds to the surface of spermatozoa from the caudal region with high affinity and in a saturable form. The binding was not inhibited by mannose-6phosphate, but was inhibited by fructose phosphate derivatives, a peculiarity previously demonstrated for the membranes of epididymal tissue. Fructose phosphate derivatives released $55 \%$ of $\beta$-galactosidase activity from the spermatozoa. These results suggest that in the epididymis there is a special transport system for hydrolases, which could be involved in the secretion of enzymes destined for spermatozoa. This transport would require receptors that recognize sugar ligands other than mannose-6-phosphate. These receptors were present in the epididymal tissue and on the sperm surface.
\end{abstract}

Keywords: epididymis; spermatozoa; $\beta$-galactosidase; rat

\section{Introduction}

Mammalian epididymal epithelium synthesizes and secretes, among other glycoproteins, significant amounts of acid hydrolases into the lumen (Conchie \& Mann, 1957; Jones \& Glover, 1973; Nikkanen \& Vanha-Perttula, 1977; Mayorga \& Bertini, 1985; Skudlarek \& Orgebin-Crist, 1986). Part of the secreted enzyme activity becomes bound to spermatozoa in the epididymis (Chapman \& Killian, 1984; Hall \& Killian, 1987).

The physiological role of these enzmyes in the epididymis and their significance in sperm maturation is uncertain, but their presence in the epididymal fluid is intriguing, since they are mostly intracellular in many tissues (De Duve et al., 1955). The amount of glycosidase activity bound to the spermatozoa changes from caput to cauda epididymidis (Hall \& Killian, 1987) but the nature of the binding has not been described.

This study examined the interaction between $\beta$-galactosidase of epididymal fluid and intact spermatozoa from the cauda epididymidis of the rat.

\section{Materials and Methods}

Preparation of epididymal spermatozoa for binding assays. Mature albino rats fed ad libitum were killed by decapitation and the epididymides were removed. The epididymal fluid and spermatozoa were obtained by perfusion of the caudal region with a $0.02 \mathrm{M}$ phosphate buffer, $\mathrm{pH} 6.5$, containing $0.15 \mathrm{M}-\mathrm{NaCl}$ as described by Mayorga \& Bertini (1985). The spermatozoa were sedimented by centrifugation at $3000 \mathrm{~g}$ for $10 \mathrm{~min}$ at $4^{\circ} \mathrm{C}$ and the supernatants were pooled. The spermatozoa were washed twice with $5 \mathrm{ml}$ of $0.3 \mathrm{M}-\mathrm{KCl}$ in the phosphate buffer and once with $5 \mathrm{ml}$ of the buffer alone. Finally, the spermatozoa were diluted with the buffer (at $10^{8}$ spermatozoa $/ \mathrm{ml}$ ) and stored at $4{ }^{\circ} \mathrm{C}$ for the binding assay. The residual activity of $\beta$-galactosidase was 0.019 units $/ 10^{5}$ spermatozoa.

*Reprint requests. 
Preparation of the enzyme. The supernatants, obtained after separation of spermatozoa from the fluid, were applied to a DEAE cellulose ionic exchange column $(1 \times 5 \mathrm{~cm})$ equilibrated with the phosphate buffer as described by Sosa et al. (1987). Fractions containing high activities of $\beta$-galactosidase were collected and used for the binding assays.

Binding assays. From $1 \times 10^{6}$ to $2 \times 10^{6}$ spermatozoa were incubated in $1.5 \mathrm{ml}$ polypropylene tubes containing 30-240 $\beta$-galactosidase units in $250 \mu \mathrm{l}$ of cold phosphate buffer with $1 \%$ glycerol. After $45 \mathrm{~min}$ of incubation at $20^{\circ} \mathrm{C}$, $0.75 \mathrm{ml}$ of cold phosphate buffer containing $7.5 \%$ sucrose was added. The tubes were stirred in a Vortex mixer for $30 \mathrm{~s}$ and centrifuged at $800 \mathrm{~g}$ for $10 \mathrm{~min}$ in a swinging bucket rotor at $20^{\circ} \mathrm{C}$. The pellets were washed twice with the same buffer. The final sediments were resuspended in $2 \%$ Triton X-100 (Sigma) and bound $\beta$-galactosidase activity was measured.

Other binding experiments were carried out with spermatozoa previously sonicated for a few seconds or treated with $0.05 \%$ digitonin to test whether the integrity of membrane is necessary in the spermatozoa-enzyme interaction.

Release of the enzyme. From $1 \times 10^{6}$ to $2 \times 10^{6}$ spermatozoa were washed twice with the phosphate buffer and incubated at $20^{\circ} \mathrm{C}$ for $30 \mathrm{~min}$ in $3 \mathrm{ml}$ polypropylene tubes in $3 \mathrm{ml}$ of the same buffer containing either $25 \mathrm{~mm}$ fructose1,6-biphosphate buffer, $25 \mathrm{~mm}$ mannose-6-phosphate or $0.6 \mathrm{M}-\mathrm{KCl}$. After the incubation, the spermatozoa were centrifuged at $800 \mathrm{~g}$ for $10 \mathrm{~min}$ and the $\beta$-galactosidase activity was measured in both supernatants and sediments resuspended in $2 \%$ Triton $\mathrm{X}-100$.

Chemical analysis. The activity of $\beta$-galactosidase was measured fluorometrically (Barret \& Heath, 1977) using $0.8 \mathrm{~mm}$ 4-methylumbelliferyl- $\beta$-D-galactopiranoside (Sigma, St Louis, USA) as the substrate in 0.13M sodium citrate buffer, $\mathrm{pH} 4$. After 30 or $60 \mathrm{~min}$ at $37^{\circ} \mathrm{C}$, the reaction was stopped by the addition of $\mathrm{I} \mathrm{ml} \mathrm{of} 0.4 \mathrm{M}$ sodium glycine buffer, $\mathrm{pH} 10.4$. One unit of activity represents the amount of enzyme that catalyses the release of $1 \mathrm{nmol}$ of 4-methylliferone/h. Proteins were measured according to Lowry et al., 1951.

\section{Results}

The results indicated that $\beta$-galactosidase is bound with high affinity and in saturable form by membranes of intact spermatozoa from the caudal region of the epididymis. Assuming that the specific activity of this enzyme is similar to that of human liver $\beta$-galactosidase, $0 \cdot 19$ units/fmol (Norden et al., 1974), the $\mathrm{K}_{\mathrm{D}}$ calculated from the Scatchard plot was $1.3 \mathrm{~nm}$ and the number of affinity sites per cell was $3.95 \times 10^{-3} \mathrm{nmol}$ (Fig. 1).

The enzyme activity found in buffered $0 \cdot 3 \mathrm{M}-\mathrm{KCl}$ used to wash spermatozoa before binding was $97 \%$ soluble after centrifuging at $100000 \mathrm{~g}$ for $30 \mathrm{~min}$, indicating that the integrity of sperm plasmalemma was preserved during washing.

Sonication or digitonin treatment caused typical unspecific adsorption of $\beta$-galactosidase, showing that integrity of the sperm plasmalemma is necessary for the binding (Fig. 2).

The amount of epididymal $\beta$-galactosidase specifically bound to caudal spermatozoa increased linearly with the number of spermatozoa in the system (Fig. 3).

The enzymatic activity per $10^{6}$ cells before washing with $\mathrm{KCl}$ was $\sim 1.0 \mathrm{U}$ and it dropped to $0 \cdot 2$ after washing. We think that the activity found in binding experiments is higher than that in vivo because proteins competing for the binding sites are eliminated with washing.

Mannose-6-phosphate, a marker group on lysosomal enzyme molecules for their recognition by membranes of various tissues (Fisher et al., 1980; Robbins et al., 1981; Brown \& Farquhar, 1984; Salminen \& Marjomaki, 1985) did not significantly inhibit the binding of epididymal $\beta$-galactosidase to spermatozoa.

The fructose-6-phosphate derivatives were the most inhibitory compounds among the sugars tested (Table 1). This inhibitory effect was confirmed when fructose-1,6-biphosphate was used to displace residual enzyme activity of the washed caudal spermatozoa in these experiments. Approximately $60 \%$ of residual enzyme activity was released by this sugar at a concentration of $25 \mathrm{mmol} / 1$ (Fig. 4). The activity of $\beta$-galactosidase was not inhibited by fructose-1,6-biphosphate at the concentrations used (data not shown).

The binding characteristics observed are similar to those noted for the epididymal membrane system (Sosa et al., 1987): optimal $\mathrm{pH} \mathrm{7,} \mathrm{resistant} \mathrm{to} \mathrm{acid} \mathrm{pH}$ and bivalent cations not required (Fig. 5 and Table 2). 

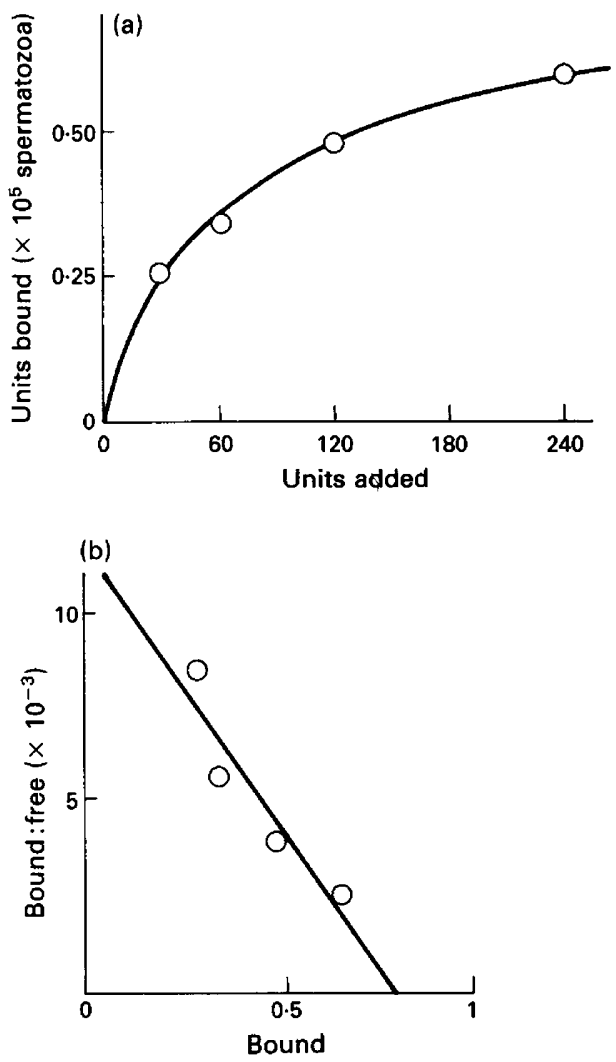

Fig. 1. (a) Binding of $\beta$-galactosidase of epididymal fluid to intact spermatozoa in rats as a function of enzyme concentration. (b) Scatchard plot of the points.

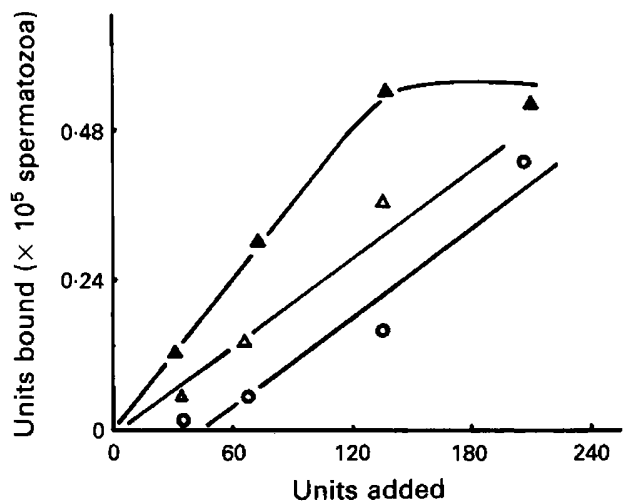

Fig. 2. Binding of $\beta$-galactosidase from rat epididymal fluid to intact spermatozoa $(\boldsymbol{\Delta})$, spermatozoa treated with buffered 0.05 digitonin $(O)$ and spermatozoa sonicated for $5 \mathrm{~s}(\triangle)$.

\section{Discussion}

The mammalian epididymis synthesizes and actively secretes acid hydrolases into the lumen (Conchie \& Mann, 1957; Jones \& Glover, 1973; Nikkanen \& Vanha-Perttula, 1977; Mayorga \& Bertini, 1985; Skudlarek \& Orgebin-Crist, 1986). Part of the activity of these enzymes becomes 


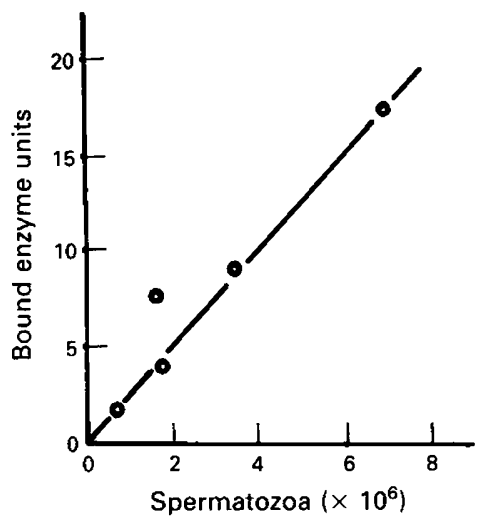

Fig. 3. Binding of $\beta$-galactosidase from rat epididymal fluid to spermatozoa as a function of the number of spermatozoa added.

Table 1. Binding of $\beta$-galactosidase of rat epididymal fluid to spermatozoa of the cauda epididymidis in the presence of carbohydrates

\begin{tabular}{lc}
\hline & $\begin{array}{c}\text { Bound enzyme } \\
\text { activity } \\
\text { (\% of control) }\end{array}$ \\
Added sugar & 79 \\
\hline Phosphorylated $(20 \mathrm{mmol} / \mathrm{l})$ & 62 \\
Mannose-6-phosphate & 96 \\
Galactose-6-phosphate & 32 \\
$N$-Acetylglucosamine-6-phosphate & 23 \\
Fructose-6-phosphate & 92 \\
Fructose-1, 6-biphosphate & 105 \\
Glucose-6-phosphate & 118 \\
Non-phosphorylated (50 mmol/l) & 101 \\
Mannose & 67 \\
Fucose & 97 \\
Galactose & \\
Glucose & \\
Sucrose & \\
\hline The binding mixture contained $1 \times 10^{6}$ to $2 \times 10^{6}$ sper- \\
matozoa, 60 U of the enzyme and the corresponding \\
sugar at the indicated concentrations. The results are \\
expressed as a percentage of the control in the absence \\
of the carbohydrates. Each value represents the mean \\
of two assays with a maximum s.d. of $6 \%$.
\end{tabular}

bound to spermatozoa during their transit through the duct (Chapman \& Killian, 1984; Hall \& Killian, 1987). It was not known whether these enzymes become associated with, tightly bound to, or incorporated into the plasma membrane of the spermatozoa.

The present study indicates the possible existence of high-affinity sites for $\beta$-galactosidase on the surface of rat spermatozoa. We have demonstrated that $\beta$-galactosidase from epididymal fluid binds to intact spermatozoa with high affinity $\left(K_{D}\right.$ in the order of $\left.M\right)$ and in a saturable form. As previously demonstrated for rat epididymal membranes (Sosa et al., 1987), the sperm surface recognizes a marker group different from mannose-6-phosphate on the molecule of $\boldsymbol{\beta}$-galactosidase (Table 1). We consider the present results are of particular interest since they point to the existence 


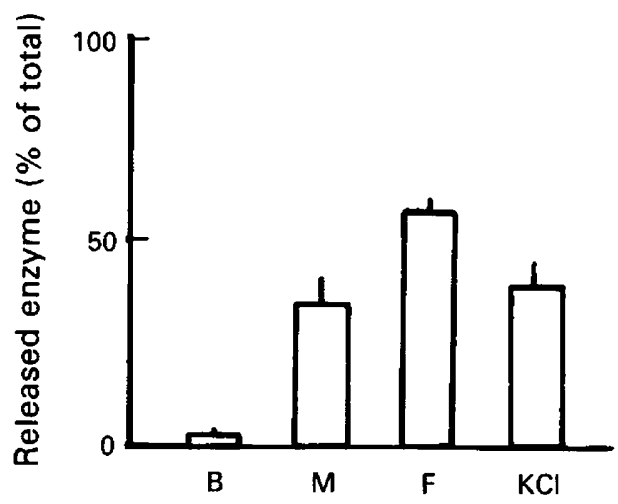

Fig. 4. Release of $\beta$-galactosidase from rat caudal epididymal spermatozoa with phosphate buffer alone (B), 20mM mannose-6-phosphate (M), 20mM fructose-1,6-biphosphate (F) and $0.6 \mathrm{M}-\mathrm{KCl}$. The released enzyme in each treatment was expressed as a percentage of the total activity measured in the presence of Triton X-100. Vertical lines indicate s.d. of 3 assays.

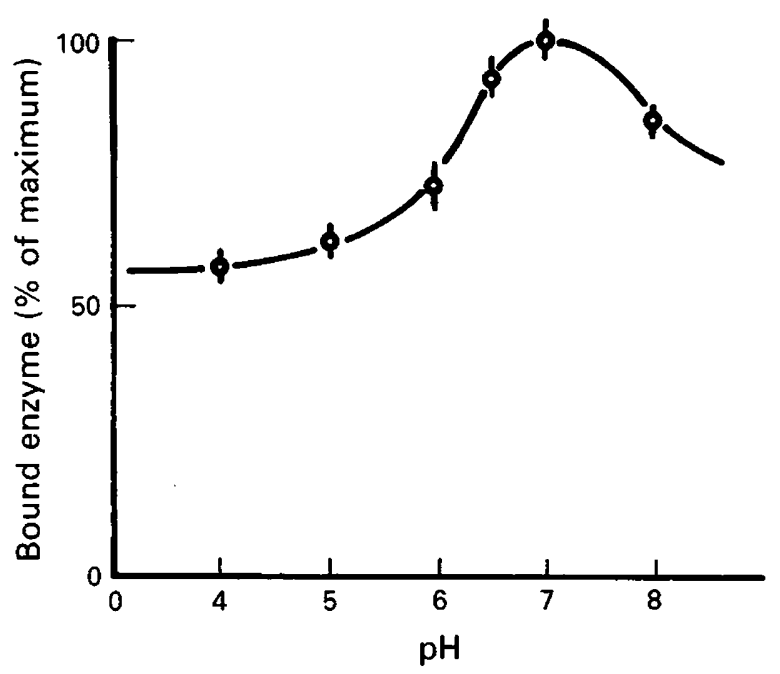

Fig. 5. Effect of $\mathrm{pH}$ on the binding of $\beta$-galactosidase from rat epididymal fluid to spermatozoa of cauda epididymidis. Bound activity at each $\mathrm{pH}$ is expressed as a percentage of the highest linked activity. Vertical lines indicate s.d. of 4 assays.

in the epididymis of a special system for the transport of lysosomal enzymes distinct from the phosphomannosyl receptor-mediated system widely described in various tissue (Fisher et al., 1980; Robbins et al., 1981; Brown \& Farquhar, 1984; Salminen \& Marjomaki, 1985; Von Figura \& Hasilik, 1986; Pfeffer, 1988). The results also suggest that $\beta$-galactosidase is secreted by the epididymis in order to be transferred onto the sperm surface.

As observed for epididymal tissue, the binding of $\beta$-galactosidase to spermatozoa was inhibited by fructose-6-phosphate derivatives (Table 1). The presence of fructose derivates has not been detected among the oligosaccharides of the glucoproteins (Marshall, 1971; Farquhar, 1985). We consider that a molecule similar to fructose phosphate derivatives may be involved in the composition of the recognition marker. The sugars of the purified epididymal enzyme are currently being analysed in this laboratory. 
Table 2. Requirements of bivalent cations for the binding of $\beta$-galactosidase of rat epididymal fluid to spermatozoa of the cauda epididymidis

\begin{tabular}{lcc}
\hline $\begin{array}{l}\text { Added } \\
\text { compound }\end{array}$ & $\begin{array}{c}\text { Concentration } \\
\text { (mmol/l) }\end{array}$ & $\begin{array}{c}\text { Bound enzyme } \\
\text { (\% of conirol) }\end{array}$ \\
\hline $\mathrm{CaCl}_{2}$ & 2 & 103 \\
$\mathrm{CaCl}_{2}$ & 5 & $98 \cdot 5$ \\
$\mathrm{MnCl}_{2}$ & 5 & 110 \\
$\mathrm{MgCl}_{2}$ & 5 & 96 \\
EDTA & 5 & $77 \cdot 5$ \\
$\mathrm{CaCl}_{2}+$ EDTA & 2 & 103 \\
\hline
\end{tabular}

The binding assays were in $0.02 \mathrm{M}$ Tris- $\mathrm{HCl}$ buffer, $\mathrm{pH}$ 6.5. The results are expressed as percentage of the control without agents. Each value represents the mean of two assays with a maximum s.d. of $8 \%$.

The $\beta$-galactosidase activity that remains bound to the spermatozoa after washing was displaced by the sugar that inhibited the binding fructose-1,6-phosphate (see Fig. 4). This strongly suggests that $\beta$-galactosidase is not incorporated into the plasma membrane of the spermatozoa, but becomes specifically bound to the sperm surface during transit through the epididymis.

The evidence presented here, with our previous observations (Sosa et al., 1987), suggests that $\beta$-galactosidase is synthesized by the epididymal epithelium, and that it is secreted into the lumen by a special receptor system that also permits the binding of the enzyme to the sperm surface. The adhesion of the enzyme to spermatozoa appears to be favoured by the $\mathrm{pH}$ of the luminal fluid (Levine \& Kelly, 1978), since it is similar to the optimal pH for binding (Fig. 5). The present results indicate the importance of the epididymis as a secretory model for lysosomal enzymes. They also point to a possible role in sperm maturation and fertilization processes for these acid hydrolases (Kohane et al., 1980; Voglmayr et al., 1980; Brooks, 1981; White et al., 1987). Finally, they indicate the existence of a highly developed and active lysosomal apparatus in the epithelial cells lining the duct, as proposed by Mayorga \& Bertini $(1981,1983)$.

We thank M. G. de Veca for valuable technical assistance and E. Soler for correcting the manuscript. This work was supported by a grant from the Consejo Nacional de Investigaciones Científicas y Técnicas de la república Argentina (CONICET).

\section{References}

Barret, A.J. \& Heath, M.F. (1977) Lysosomal enzymes. In: Lysosomes: a Laboratory Handbook, pp. 118-120. Ed. J. T. Dingle. Elsevier/North-Holland and Biomedical Press, Amsterdam.

Brown, W.J. \& Farquhar, M.G. (1984) The mannose6-phosphate receptor for lysosomal enzymes is concentrated in cis Golgi cisternae. Cell 36, 295-307.

Brooks, D.E. (1981) Secretion of proteins and glycoproteins by the rat epididymis: regional differences, androgen-dependence, and effects of protease inhibitors, procaine and tunicamicin. Biol. Reprod. 25, 1099-1117.

Chapman, D.E. \& Killian, G.J. (1984) Glycosidase activities in principal cells, basal cells, fibroblasts and spermatozoa isolated from the rat epididymis. Biol. Reprod. 31, 627-630.
Conchie, J. \& Mann, T. (1957) Glycosidase in mammalian sperm and seminal plasma. Nature, Lond. 179, 1190-1191.

De Duve, C., Pressman, B.C., Gianetto, R., Wattiaux, R. \& Appelmans, F. (1955) Tissue fractionation studies. Intracellular distribution patterns of enzymes in rat-liver tissue. Biochem. J. 60, 604-617.

Farquhar, M.G. (1985) Progress in unraveling pathways of Golgi traffic. A. Rev. Cell Biol. 1, 447-488.

Fisher, H.D., Gonzalez-Noriega, A., Sly, W.S. \& Morre, D.J. (1980) Phosphomannosylenzyme receptor in rat liver. J. biol. Chem. 255, 9608-9615.

Hall, J.C. \& Killian, G.J. (1987) Changes in rat sperm membrane glycosidase activities and carbohydrate and protein contents associated with epididymal transit. Biol. Reprod. 36, 709-718. 
Jones, R. \& Glover, T.D. (1973) The collection and composition of epididymal plasma from cauda epididymidis of the rabbit. J. Reprod. Fert. 34, 395-403.

Kohane, A.C., Gonzalez Echeverria, M.F.C., Piñeiro, L. \& Blaquier, J.A. (1980) Interaction of proteins of epididymal origin with spermatozoa. Biol. Reprod. 23, 737-742.

Levine, N. \& Kelly, H. (1978) Measurement of $\mathrm{pH}$ in the rat epididymis in vivo. J. Reprod. Fert. 52, 333-335.

Lowry, O.H., Rosenbrough, N.J., Farr, A.L. \& Randall, R.J. (1951) Protein measurement with the folin phenol reagent. J. biol. Chem. 193, 265-275.

Marshall, R.D. (1971) Glycoproteins. A. Rev. Biochem. 40, 673-702.

Mayorga, L.S. \& Bertini, F. (1981) Acid hydrolases in the epididymis of normal, castrated, vasectomized, cryptorchid and cryptepididymal rats. Int. J. Androl. 4, 208-219.

Mayorga, L.S. \& Bertini, F. (1983) Latency and bound activity of acid hydrolases for the study of lysosomal heterogeneity in rat epididymis. Microsc. Electr. Biol. Cell. 7, 85 9I.

Mayorga, L.S. \& Bertini, F. (1985) The origin of some acid hydrolases of the fluid of the rat cauda epididymidis. J. Androl. 6, 243-245.

Nikkanen, V. \& Vanha-Perttula, T. (1977) Acid phosphatase of the rat epididymis III. Histochemical and Biochemical responses in experimental conditions. Andrologia 9, 357-370.

Norden, A.G.W., Tennant, L.L. \& O'Brien, J.S. (1974) $\mathrm{GM}_{1}$ ganglioside $\beta$-galactosidase. A purification and study of the enzyme from human liver. J. biol. Chem. 249, 7969-7972.
Pfeffer, S.R. (1988) Mannose-6-phosphate receptor and their role in targeting proteins to lysosomes. $J$. Membrane Biol. 103, 7-16.

Robbins, A.R., Youle, R.J., Murray, G.J., Neville, D.M. \& Myerwitz, R. (1981) The mannose-6-phosphate receptor of Chinese hamster ovary cells. J. biol. Chem. 256, 10618-10622.

Salminen, A. \& Marjomaki, V. (1985) Phosphomannosyl receptors of lysosomal enzymes in cardiac and skeletal muscles of young and old mice. Comp. Biochem. Physiol. 826, 259-262.

Skudlarek, M.C. \& Orgebin-Crist, M.C. (1986) Glycosidases in cultured rat epididymal cells; enzyme activity, synthesis and secretion. Biol. Reprod. 35, 167-178.

Sosa, M.A., Mayorga, L.S. \& Bertini, F. (1987) $\beta$ galactosidase from rat epididymal fluid is bound by a recognition site attached to membranes of the epididymis different from the phosphomannosyl receptor. Biochem. biophys. Res. Commun. 143, 799-807.

Volgmayr, J.C., Fairbanks, G., Jakowitz, M.A. \& Colella, J.R. (1980) Post-testicular developmental changes in the ram sperm cell surface and their relationship to luminal fluid proteins of the reproductive tract. Biol. Reprod. 22, 655-667.

Von Figura, K. \& Hasilik, A. (1986) Lysosomal enzymes and their receptors. A. Rev. Biochem. 55, 187-193.

White, I.G., Goh, P. \& Volgmayr, J.K. (1987) Effect of male reproductive tract fluids and proteins on the metabolism and motility of ram spermatozoa. Arch. Androl. 19, 115-125.

Received 11 June 1990 